\title{
Isolation and Evaluation of Binding property of Lannea coromandelica gum
}

\author{
D. LOHITHASU* AND K. V. RAMANA MURTHY
}

Division of Pharmaceutical Technology, Andhra University College of Pharmaceutical Sciences, Visakhapatnam-530 003, India

Lohithasu and Ramana Murthy: Evaluation of Binding Property of Lannea coromandelica Gum

\begin{abstract}
The objective of this present study was to investigate binder property of Lannea coromandelica in tablet formulations and its comparative binding property with povidone as standard binder. All the eight tablet batches (F-1 to F-8) were prepared by wet granulation technique. Microcrystalline cellulose (Prosolv SM) as diluent, diclofenac sodium as model drug using 4, 6, 8 and 10\% of L. coromandelica gum used as a novel binder, magnesium stearate used as an antiadherent and talc used as lubricant. Micromeritic properties of granules such as bulk density, tapped density, compressibility index, Hausner's ratio, angle of repose as well as physical parameters of the compressed tablets like hardness, friability, thickness and disintegration time were determined and found to be satisfactory. The Fourier transform infrared spectroscopic analysis showed that the tablet formulation containing L. coromandelica gum is compatible with the drug and other excipients, which are used in the tablet formulation. Thus, concluded that $L$. coromandelica gum has role as a potential binder in tablets formulations. The in vitro drug release profile concluded that tablets formulations containing L. coromandelica gum $20 \mathrm{mg} / 200 \mathrm{mg}$ of total weight of tablet as binder showed better results as compared to povidone as standard binder.
\end{abstract}

Key words: Lannea coromandelica, plant gum, binding ability, plant natural polymer, Diclofenac sodium and FTIR studies

In the present day, polymers those are derived from plant origin play a vital role as pharmaceutical applications such as filler, binder, disintegrant in tablets, protective colloids in suspensions, thickeners in oral liquids, gelling agents in gels and bases in suppository ${ }^{[1]}$. Natural gums are obtained as an outcome of metabolic mechanism of plants from natural sources either absorbs water to form a viscous solution or water soluble ${ }^{[2]}$. Plant derived natural polysaccharides are more suitable as pharmaceutical excipients due to nontoxicity, availability, stability, renewability and are, therefore, extensively used as a matrix forming agent in modified release dosage forms ${ }^{[3]}$.

Natural gums are also useful in formulating immediate and sustained release preparations $s^{[4-6]}$. The natural excipients are preferred to synthetic and semi synthetic ones because of their lack of toxicity, soothing action, low cost, availability and non-irritant nature of the excipients also they are biocompatible, less expensive, and easily available than the synthetic ones $^{[7]}$.

The isolated gum from the tree Lannea coromandelica (gumpena) has been established to be a neutral polysaccharide composed of d-galactose and 1-arabinose in the $4: 1 \mathrm{ratio}^{[8]}$. Natural polysaccharide

*Address for correspondence

E-mail: lohithasu@gmail.com gumpena gum (GG) obtained from the plant of $L$. coromandelica (Houtt.) Merr. (Anacardiaceae). Upon injury of epithelial cells, the bark of the mature (6 to 10 year old) L. coromandelica (Houtt.) Merr. tree produces a gum that is exuded at the point of injury. The gum also exudes naturally ${ }^{[9]}$. Gumpena gum tree is abundantly found in forests of Srikakulam, Visakhapatnam and West Godavari districts in Andhra Pradesh, Rawatbhata, near Kota, Rajasthan, India.

Earlier pharmacological studies on L. coromandelica reported antiinflammatory ${ }^{[10]}$, antimicrobial ${ }^{[1,12]}$, hypotensive ${ }^{[13]}$, wound healing and aphrodisiac activities. The plant also illustrated its beneficial effect on ulcerative stomatitis, dyspepsia, general debility, gout, cholera, diarrhoea, dysentery ${ }^{[14]}$, sore eyes, leprosy, sprains and bruises ${ }^{[15]}$, elephantiasis ${ }^{[16]}$, eruptions, snakebite, stomach ache, and vaginal trouble ${ }^{[17,18]}$. The plant gum is given in sprains ${ }^{[19]}$, asthma and as a cordial to women during lactation, bark extract have antimicrobial and antifungal activity $^{[20]}$.

L. coromandelica is a medium-sized deciduous tree belonging to family Anacardiaceae. They are useful for imparting the structural strength required during the processing, handling and packaging of tablets as well as these plant gums are of non-toxic nature and widely available ${ }^{[21]}$. No work has been done on $L$. coromandelica gum as tablet binder. Hence the gum 
is widely available and need to be evaluated by using as an excipient in tablet formulations.

\section{MATERIAL AND METHODS}

Diclofenac sodium is obtained as a gift sample from Crips Laboratory Pvt. Ltd, Visakhapatnam. Microcrystalline cellulose (Prosolv SM, JRS Pharma, Germany), magnesium stearate, talc (Reachem Lab. Chemicals Pvt. Ltd, Chennai) and povidone was provided by Hetero Pharma, Hyderabad. All other chemicals used were of analytical grade.

\section{Collection and isolation of $L$. coromandelica gum from crude gum:}

Gum was collected from the plants of $L$. coromandelica in May-June, 2014 from Srikakulam and Visakhapatnam districts, India. After collection, gum was dried in oven (M/s. Shiv Scientific Services, India) at $60^{\circ}$ and removed extraneous materials from the crude gum. The gum was then precipitated from the solution using ethanol. The precipitate was separated, dried in oven at $50^{\circ}$ and ground by high speed mechanical blender (Model no. Butterfly, LCM-2306-135, India). The resultant powder was sifted through mesh no. 100 and stored in a tightly closed container for further use.

\section{Preparation and evaluation of granules:}

Granules of various formulation batches (F1F8) containing $50 \mathrm{mg}$ of diclofenac sodium were prepared by wet granulation method. Natural gum (L. coromandelica) in different ratios was used as binder and povidone as a standard binder. Diclofenac sodium, microcrystalline cellulose and gum were separately mixed and required quantity of water (as granulating agent) was added. The obtained damp mass was passed through mesh no. 12. The obtained granules were dried at $60^{\circ}$ for $4-5 \mathrm{~h}$, and then passed through mesh no. 18. Finally, magnesium stearate, talc (as antiadherent and lubricant) was added to every batch prior to compression of granules. All the formulation batches are shown in Table 1.

\section{Evaluation of granules:}

The bulk density, tapped density, Hausner's ratio, compressibility index and angle of repose were determined for each batch of dried granules.

Bulk density is the ratio of total mass of granules to the bulk volume of granules. It was measured by pouring the known weighed of granules $(\mathrm{m})$ into 10 $\mathrm{ml}$ graduated cylinder, and the unsettled volume $\left(\mathrm{V}_{0}\right)$ was noted. It is expressed in $\mathrm{g} / \mathrm{ml}$. It is calculated by, $\mathrm{m} / \mathrm{V}_{0}{ }^{[22]}$.

Tapped density is the ratio of total mass of granules to the tapped volume of granules. It is determined by placing a graduated cylinder $(10 \mathrm{ml})$ containing known weight (m) of granules, was tapped on a hard surface for fixed number of taps until the powder bed volume has reached a minimum volume. Observed tapped volume (VT) was noted. Tapped density was calculated by, m/ VT ${ }^{[23]}$.

Carr's compressibility index was determined using the formula, Carr's compressibility index $=$ (tapped density-bulk density)/ tapped density.

Hausner's ratio is the ratio of tapped density and bulk density and was calculated using the formula ${ }^{[24]}$, Hausner's ration=tapped density/bulk density.

The accurately weighed granules were taken in a funnel. The funnel height was adjusted in such a way that the tip of the funnel just touched the apex of the heap of the granules. The granules were allowed to flow through the funnel freely on to the surface. The diameter of the cone was measured (funnel method). The angle of repose $(\theta)$ values were calculated using the formula, Tan $\theta=h / r$, where $h$ is the height of the heap and $r$ is the radius of the heap.

\section{Preparation of diclofenac tablets:}

Tablets were prepared by compressing granules on compression machine using concave punch $(8 \mathrm{~mm})$. Total weight of tablet was kept as $200 \mathrm{mg}(\mathrm{M} / \mathrm{s}$. Cadmach Machinery Co. Pvt. Ltd, India).

TABLE 1: FORMULATION OF DIFFERENT BATCHES (F1-F8) OF DICLOFENAC SODIUM TABLETS

\begin{tabular}{lcccccccc}
\hline Ingredients (mg) & F1 & F2 & F3 & F4 & F5 & F6 & F7 & F8 \\
\hline Diclofenac sodium & 50 & 50 & 50 & 50 & 50 & 50 & 50 & 50 \\
L. coromandelica gum & 8 & 12 & 16 & 20 & -- & -- & -- & -- \\
Povidone & -- & -- & -- & -- & 8 & 12 & 16 & 20 \\
Prosolv SM & 133 & 129 & 125 & 121 & 133 & 129 & 125 & 121 \\
Talc & 3 & 3 & 3 & 3 & 3 & 3 & 3 & 3 \\
Magnesium stearate & 6 & 6 & 6 & 6 & 6 & 6 & 6 & 6 \\
Distilled water & q.s & q.s & q.s & q.s & q.s & q.s & q.s & q.s \\
Total weight (mg) & 200 & 200 & 200 & 200 & 200 & 200 & 200 & 200 \\
\hline
\end{tabular}




\section{Evaluation of tablets}

After compression twenty tablets were selected at random, weighed together and individually by analytical balance (AX120, M/s. Shimadzu Corporation, Japan), then average weight and standard deviation was determined ${ }^{[25]}$.

From each batch, 10 tablets were randomly collected, accurately weighed and powdered in glass mortar. Powder amount equivalent to $50 \mathrm{mg}$ of diclofenac sodium was shaken with $60 \mathrm{ml}$ of methanol in a $200 \mathrm{ml}$ volumetric flask and final volume was made up to the mark with methanol, from this solution 5 $\mathrm{ml}$ was taken, then further diluted to $100 \mathrm{ml}$ with methanol and absorbance was measured using spectrophotometer (UV-Elico Pvt. Ltd., SL 210, India) at $276 \mathrm{~nm}$. The content was determined by preparing same concentration of sodium diclofenac in the same solvent and absorbance was measured at $276 \mathrm{~nm}$. The $\%$ drug content was determined by the formula [26], \% drug content $=(($ Abs sample $\times$ average weight of tablet)/(Abs standard $\times$ weight of sample) $) \times 100$.

From each batch, the hardness of 5 tablets was determined by using Monsanto hardness tester and mean \pm SD of each formulation mentioned in Table 3. From each batch, thickness of 10 tablets was determined using vernier callipers and average values were calculated. The friability of tablets (10) was determined using Roche friabilator (EF-2, M/s. Electrolab, India). Ten tablets were initially weighed $\left(\mathrm{W}_{0}\right)$ and transferred into friabilator. The friabilator was operated at $25 \mathrm{rpm}$ for 4 minutes or was run up to 100 revolutions. The tablets were dedusted by using camel hair brush and weighed again (W). Percent friability was then calculated using the formula, $\%$ Friability $\left.=\left(\mathrm{W}_{0}-\mathrm{W}\right) / \mathrm{W}_{0}\right) \times 100$, where $\mathrm{W}_{0}$ is the initial weight of 10 tablets and $\mathrm{W}$ is the weight of 10 tablets after 100 , revolutions. \% Friability of tablets less than $1 \%$ were considered acceptable.

\section{Disintegration time:}

Disintegration test apparatus (DBK Instrument, England, 40 TDA01) containing $100 \mathrm{ml}$ of $0.1 \mathrm{~N}$ $\mathrm{HCl}$ as disintegration medium and thermostatically maintained at $37 \pm 2^{\circ}$. Six tablets from randomly selected from each batch, placing one per cylindrical tube, were tested at a time. The time taken for each of the six tablets to disintegrate was recorded and the disintegration time of each batch was calculated ${ }^{[27]}$.

\section{In vitro drug dissolution studies:}

In vitro dissolution test of the all the batches compressed diclofenac sodium tablet was performed using USP dissolution apparatus 2 (Disso 2000,M/s. Labindia, India), using $\mathrm{pH} 6.8$ phosphate buffer as dissolution medium. The temperature was maintained at $37 \pm 2^{\circ}$, at a rotation speed of $50 \mathrm{rpm}$. The $5 \mathrm{ml}$ of filtered samples were withdrawn at regular intervals up to 60 minutes, then replacing $5 \mathrm{ml}$ of fresh dissolution medium ( $\mathrm{pH} 6.8$ phosphate buffer). Samples were analysed using UV spectrophotometer at $276 \mathrm{~nm}$ absorbance and \% drug release was calculated.

\section{Release kinetics:}

The mechanism of drug release from the tablets was studied by the release data were fitted to zero-order, first-order, Higuchi's, and Korsmeyer's Eqns. Zeroorder Eqn. is $\mathrm{Q}=\mathrm{Q}_{0}-\mathrm{k}_{0} \mathrm{t}$, where $\mathrm{Q}$ is the amount of drug release at time $t$, and $\mathrm{k}_{0}$ is the release rate; firstorder Eqn. is $\ln \mathrm{Q}=\ln \mathrm{Q}_{0}-\mathrm{k}_{1} \mathrm{t}$, where $\mathrm{k}_{1}$ is the release rate constant; and Higuchi's Eqn is $\mathrm{Q}=\mathrm{k}_{2} \mathrm{t}^{1 / 2}$, where $\mathrm{Q}$ is the amount of drug release at time $t$ and $k_{2}$ is the diffusion rate constant ${ }^{[28,29]}$.

\section{FTIR Studies:}

To study any possible interaction between drug and the plant gum, FTIR spectroscopic analysis were carried out. The drug sample, gum and optimized formulation blend i.e. batch F-3 (blend contains gum, diclofenac sodium, prosolv SM, talc and magnesium

TABLE 2: EVALUATION OF GRANULES

\begin{tabular}{|c|c|c|c|c|c|c|c|c|}
\hline Properties* & F1 & F2 & F3 & F4 & F5 & F6 & F7 & F8 \\
\hline $\begin{array}{l}\text { Bulk density } \\
(\mathrm{g} / \mathrm{ml})\end{array}$ & $0.567 \pm 0.00$ & $0.582 \pm 0.01$ & $0.601 \pm 0.01$ & $0.601 \pm 0.00$ & $0.487 \pm 0.00$ & $0.489 \pm 0.00$ & $0.484 \pm 0.00$ & $0.603 \pm 0.01$ \\
\hline $\begin{array}{l}\text { Tapped } \\
\text { density (g/ml) }\end{array}$ & $0.626 \pm 0.01$ & $0.652 \pm 0.01$ & $0.662 \pm 0.01$ & $0.65 \pm 0.01$ & $0.583 \pm 0.00$ & $0.578 \pm 0.00$ & $0.58 \pm 0.01$ & $0.664 \pm 0.01$ \\
\hline Carr's index & $9.42 \pm 0.59$ & $10.73 \pm 0.54$ & $8.93 \pm 0.29$ & $7.53 \pm 0.94$ & $16.46 \pm 0.72$ & $15.39 \pm 0.84$ & $16.55 \pm 0.56$ & $9.18 \pm 0.09$ \\
\hline $\begin{array}{l}\text { Hausner's } \\
\text { ratio }\end{array}$ & $1.104 \pm 0.01$ & $1.12 \pm 0.00$ & $1.101 \pm 0.00$ & $1.081 \pm 0.01$ & $1.197 \pm 0.00$ & $1.182 \pm 0.01$ & $1.198 \pm 0.00$ & $1.101 \pm 0.01$ \\
\hline $\begin{array}{l}\text { Angle of } \\
\text { repose }\left({ }^{\circ}\right)\end{array}$ & 02 & 31.41 & 31 & 34 & 35.86 & 34.09 & 33.47 & 30.32 \\
\hline
\end{tabular}

${ }^{*}$ All the values are expressed as mean \pm SD 
stearate) compatibility were studied by $\mathrm{KBr}$ pellet method using FTIR spectrophotometer (M/s. PerkinElmer, 841, Spectrum one). A small amount of diclofenac sodium, gum and formulation blend were respectively placed directly on the germanium piece of the infrared spectrometer with constant pressure applied and infrared absorbance data was collected over the wave number ranged from $4000 \mathrm{~cm}-1$ to 400 $\mathrm{cm}^{-1}$ and was expressed in $\mathrm{cm}^{-1[29]}$.

\section{RESULTS AND DISCUSSION}

The current study was undertaken to evaluate the binding potential of $L$. coromandelica gum using diclofenac sodium was used as model drug in tablets. The granules of different formulation batches prepared (Table 1) were evaluated different parameters like angle of repose $(\theta)$, bulk and tapped densities, compressibility index, Hausner's ratio and the results are shown in Table 2. Angle of repose of all the formulated batches ranges from 29.31 to 34.09, indicating good low properties. Physical characterization of all the batches (Table 3) showing acceptable values of thickness, weight variation (ranged from 199.25 \pm 3.76 to $202.50 \pm 3.27$ ) was found within limit i.e. \pm 7.5 for the $200 \mathrm{mg}$ tablet as per USP, hardness (ranged from $5-6 \mathrm{~kg} / \mathrm{cm}^{2}$ ), friability (ranged from 0.16 to $0.69 \%$ ) within the acceptance range i.e. less than $1 \%$, disintegration time ( $<15 \mathrm{~min}$ ) was found to be acceptable as all the batches and drug content (ranged from $98.05 \pm 0.55$ to $100.14 \pm 1.09 \%$ ) was that claimed.

In vitro dissolution in phosphate buffer $\mathrm{pH} 6.8$, batch F-3 (containing 10\% gum per total weight of tablet) release showed $79.95 \%$ of drug releases at the end of $50 \mathrm{~min}$, which is compared with F-7 (containing standard binder povidone at $8 \%$ of total weight of tablet) formulation showed $87.23 \%$ drug release at the end of 30 min. Batch F-4 (containing 10\% of gum) showed $76.53 \%$ drug release at the end of 60 min. Batch F-8 released $98.24 \%$ drug at the end of $60 \mathrm{~min}$. Hence, it can be concluded that the binding potential of $L$. coromandelica better as compared to povidone. These results are shown in fig. 1.

\section{TABLE 3: PHYSICAL CHARACTERIZATION OF DICLOFENAC SODIUM TABLETS}

\begin{tabular}{ccccccc}
\hline Formulation & $\begin{array}{c}\text { Hardness } \\
\left(\mathbf{k g} / \mathbf{c m}^{2}\right)\end{array}$ & $\begin{array}{c}\text { Weight variation } \\
(\%)\end{array}$ & $\begin{array}{c}\text { Thickness } \\
(\mathbf{m m})\end{array}$ & $\begin{array}{c}\text { Friability* } \\
(\%)\end{array}$ & $\begin{array}{c}\text { Disintegration } \\
\text { time* }\end{array}$ & $\begin{array}{c}\text { Drug content } \\
(\%)\end{array}$ \\
\hline F1 & $5-6$ & $200.60 \pm 3.24$ & $4.33 \pm 1.03$ & 0.69 & 3.2 & $98.05 \pm 0.55$ \\
F2 & $5-6$ & $200.20 \pm 3.15$ & $4.31 \pm 1.02$ & 0.53 & 8.1 & $98.95 \pm 0.65$ \\
F3 & $5-6$ & $200.10 \pm 2.58$ & $4.34 \pm 0.53$ & 0.16 & 8.8 & $100.11 \pm 0.58$ \\
F4 & $5-6$ & $200.67 \pm 3.22$ & $4.31 \pm 1.10$ & 0.42 & 14.1 & $100.14 \pm 1.09$ \\
F5 & $5-6$ & $199.25 \pm 3.76$ & $4.36 \pm 1.10$ & 0.38 & 4.4 & $98.42 \pm 0.72$ \\
F6 & $5-6$ & $202.50 \pm 3.27$ & $4.35 \pm 1.03$ & 0.28 & 9.0 & $100.01 \pm 0.96$ \\
F7 & $5-6$ & $200.38 \pm 3.36$ & $4.29 \pm 0.81$ & 0.17 & 14.4 & $99.26 \pm 1.04$ \\
F8 & $5-6$ & $200.19 \pm 2.48$ & $4.30 \pm 0.52$ & 0.32 & 9.4 & $99.34 \pm 0.98$ \\
\hline
\end{tabular}

${ }^{*}$ All the values are expressed as mean \pm SD except data denoted by asterisk

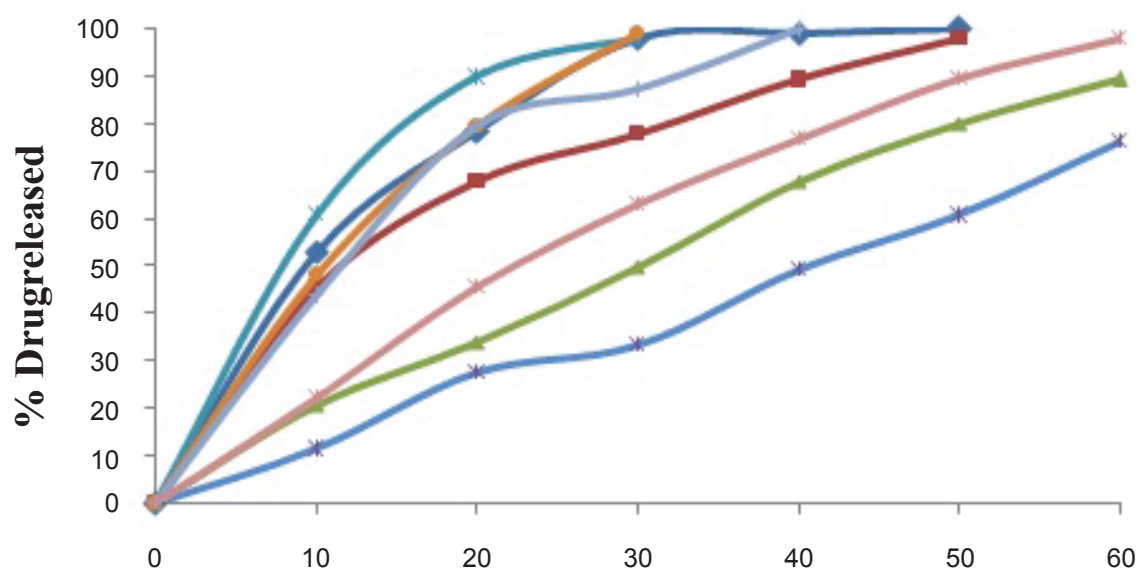

Time(min)

Fig. 1: In vitro drug release profile of diclofenac sodium tablets.

In vitro drug release profile of diclofenac sodium tablets from various formulations; F1 (-४-); F2 (-匹-); F3 (- A-); F4 (-×-); F5 (-ж-); F6 (-•-); F7 $(-+-) ;$ F8 (-*-) 
All the batches obey zero order kinetics with ' $\mathrm{R}^{2}$ ' values of $0.8910,0.9407,0.9954,0.9969,0.9386$, 0.9818, 0.9502, 0.9869 for F-1, F-2, F-3, F-4, F-5, F-6, F-7 and F-8, respectively. Formulation batch F-5 follow Fickian (Case I) release, as evident from the Table 4. A value of $\mathrm{n}=0.45$ indicates Fickian (case I) release; $>0.45$ but $<0.89$ for non-Fickian (anomalous) release; and $>0.89$ indicates super case II type of release. Case II generally refers to the erosion of the polymeric chain and anomalous transport (non-
Fickian) refers to a combination of both diffusion and erosion controlled-drug release.

Drug-excipient compatibilities studies were carried out by using FTIR spectroscopy. FTIR Spectra of drug (diclofenac sodium) and optimized formulation F-4 (drug, excipients and gum mixture) were analysed. The FTIR spectra of pure diclofenac sodium and its physical mixtures with other excipients are shown in fig. 2 and interpretations were listed in Table 5. The

TABLE 4: RELEASE KINETICS OF VARIOUS FORMULATIONS

\begin{tabular}{ccccccc}
\hline \multirow{2}{*}{ Formulation } & Zero Order & First Order & Higuchi & Hixson Crowell & \multicolumn{2}{c}{ Korsmeyer } \\
\cline { 2 - 6 } & $\mathbf{R}^{\mathbf{2}}$ & $\mathbf{R}^{\mathbf{2}}$ & $\mathbf{R}^{\mathbf{2}}$ & $\mathbf{R}^{\mathbf{2}}$ & $\mathbf{R}^{\mathbf{2}}$ & $\mathbf{n}$ \\
\hline F1 & 0.8910 & 0.7362 & 0.9797 & 0.9899 & 0.9612 & 1.211 \\
F2 & 0.9407 & 0.7563 & 0.9979 & 0.9919 & 0.9679 & 1.186 \\
F3 & 0.9954 & 0.8282 & 0.9715 & 0.9929 & 0.9934 & 1.098 \\
F4 & 0.9969 & 0.8694 & 0.9534 & 0.9904 & 0.9984 & 1.048 \\
F5 & 0.9386 & 0.8264 & 0.9949 & 0.9974 & 0.9792 & 0.447 \\
F6 & 0.9818 & 0.8532 & 0.9944 & 0.9843 & 0.9864 & 1.404 \\
F7 & 0.9502 & 0.8024 & 0.9914 & 0.9844 & 0.9792 & 1.294 \\
F8 & 0.9869 & 0.8105 & 0.9828 & 0.9869 & 0.9909 & 1.133 \\
\hline
\end{tabular}
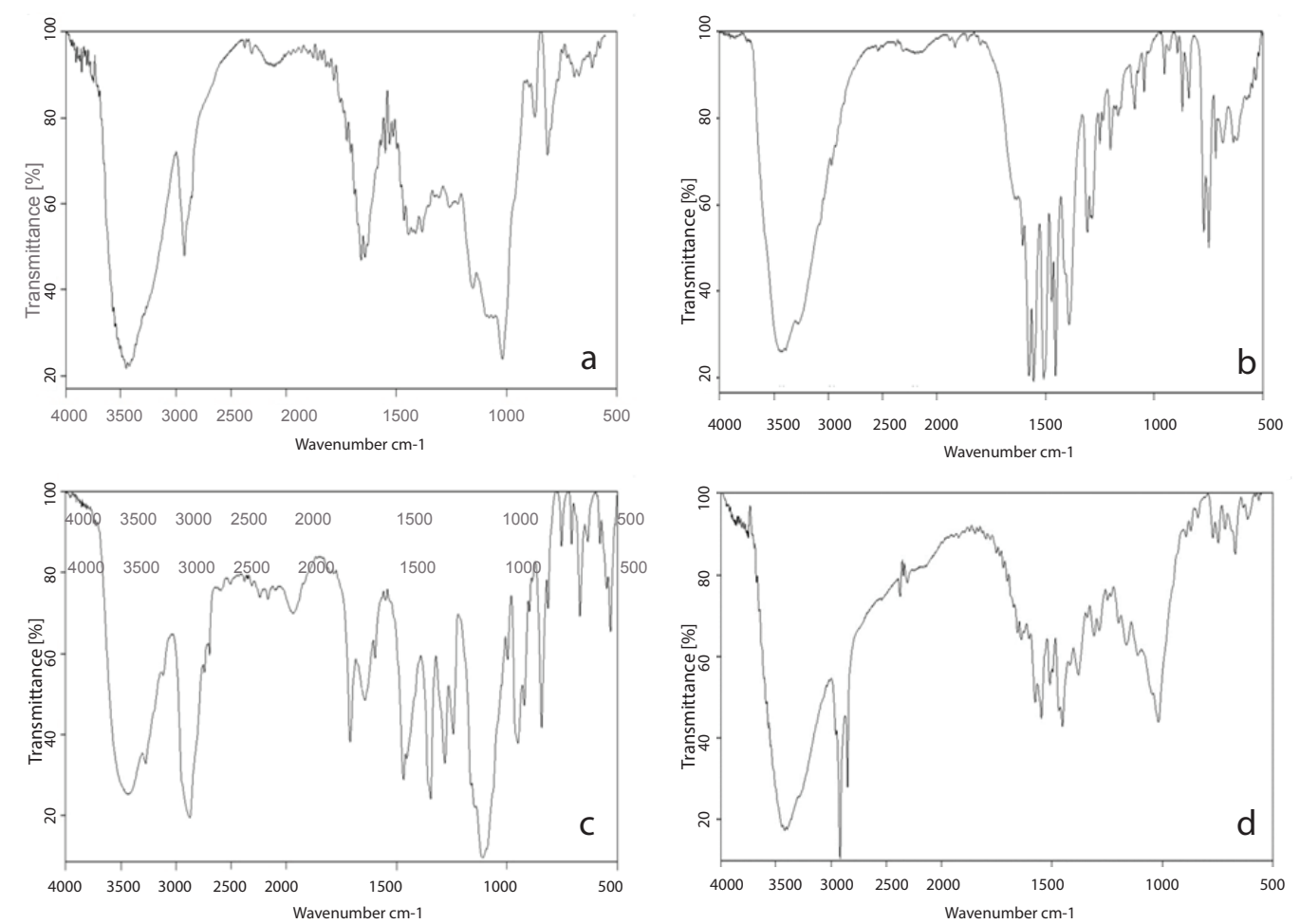

Fig. 2: FTIR spectra.

FTIR spectrum of Lannea coromandelica gum (a); diclofenac sodium (b); F-4 formulation blend containing L. coromandelica gum (c); (d) F-8 formulation blend containing povidone

\section{TABLE 5: FTIR DATA INTERPRETATION}

\begin{tabular}{ccccc}
\hline Bonds/Group & Absorption range $\left(\mathbf{c m}^{-1)}\right.$ & Pure drug $\left(\mathbf{c m}^{-1}\right)$ & Formulation F-4 $\left(\mathbf{c m}^{-1}\right)$ & Formulation F-8 $\left(\mathbf{c m}^{-1}\right)$ \\
\hline C-C & $850-550$ & 770.5 & 812.4 & 771.8 \\
C-N & $1300-800$ & 1045.1 & 996.6 & 1018.8 \\
C-Cl & $1280-1350$ & 1284.4 & 1280.6 & 1286.1 \\
C=C & $1900-1500$ & 1574.9 & 1560.0 & 1547.8 \\
C-H & $3100-2850$ & 2968.6 & 2873.6 & 2851.0 \\
-NH & $3500-3200$ & 3424.8 & 3430.5 & 3421.3 \\
\hline
\end{tabular}


distinct peaks of pure drug were at 770.5, 1045.1, $1284.4,1574.9,2968.6,3424.8 \mathrm{~cm}^{-1}$, while the F4 batch containing $L$. coromandelica gum as binder showed peaks at 812.4, 996.6, 1280.6,1560.0,2873.6 and $3430.5 \mathrm{~cm}^{-1}$. The distinct peaks are appeared in both pure L. coromandelica gum, indicating no chemical interaction between diclofenac sodium and L. coromandelica gum as confirmed by FTIR. Hence, the gum is safe to use as an excipient in formulation of diclofenac sodium tablets.

Batch F-3 release showed $77.80 \%$ of drug releases at the end of $30 \mathrm{~min}$, which is compared with F-7 formulation, showed $87.23 \%$ drug release at the end of $30 \mathrm{~min}$. Hence, it is concluded that L. coromandelica has better binding potential as compared to povidone. Hence, L. coromandelica gum, a natural excipient, can be used as a binder in tablet formulations.

\section{ACKNOWLEDGEMENTS}

The others thank Crips Laboratory Pvt. Ltd. for diclofenac sodium as gift sample for this work.

\section{FINANCIAL ASSISTANCE}

None.

\section{CONFLICT OF INTERESTS}

None declared.

\section{REFERENCES}

1. Zatz JL, Kushla GP. Oral aqueous suspensions and gels. In, Reiger MM, Banker GS. Editors, Pharmaceutical Dosage Forms: Disperse Systems. Vol. 2. New York: Marcel Dekker; 1989, p.164-405.

2. Sarojini S, Deepthi S, Kunam MR, Jayanthi B. Effect of natural almond gum as a binder in the formulation of diclofenac sodium tablets. Int J Pharm Sci Res 2010;1:55-60.

3. Beneke EC, Viljoen AM, Hamman JH. Plantderived excipients in drug delivery. Molecules 2009;14:2602-20.

4. Ibrahim MA, Dawes VH, Bangudu AB. Evaluation of Cissus populnea polymer as a matrix former for controlled drug release. J Phytomed Therap 2000;5:23-32.

5. Sinha VR, Kumaria R. Binders for colon speciic drug delivery: an in vitro evaluation. Int J Pharm 2002;249:23-31.

6. Emeje M, Nwabunike P, Isimi C, Fortunak J, Mitchell J.W, Byrn $\mathrm{S}$, et al. Isolation, characterization and formulation properties of a new plant gum obtained from Cissus refescence. Afr J Pharm Pharmacol 2009;3:16-23.

7. Kulkarni GT, Gowthamarajan K, Dhobe R, Yohanan F, Suresh B. Development of controlled release spheriods using natural polysaccharide as release modifier. Drug Delivery 2005;12:201-6.

8. Ramachandran R, Bhuwan CJ. Examination of the gum from Lannea coromandelica. Phytochem 1968;7:2057-9.

9. Reddy AK, Joy JM, Kumar A. Lannea coromandelica: The researcher's tree. J Pharm Res 2011;4:577-9.

10. Saravanan $\mathrm{S}$, Dhasarathan $\mathrm{P}$, Indira $\mathrm{V}$, Venkataraman R. Screening of antiinflammatory potential of chosen medicinal plants using swiss albino mice. Aust J Basic Appl Sci 2010;4:6065-8.

11. Basuri TS, Patil C, Dhal NK. In vitro evaluation of antibacterial activity of crude ethanolic extract of Lannea coromandelica. J Pharm Res 2011;4:1246-47.

12. Sathish R, Mohd HA, Natarajan K, Lalitha KG. Evaluation of wound healing and antimicrobial activity of Lannea coromandelica (Houtt) Merrill. J Pharm Res 2010;3:1225-8.

13. Singh S, Singh GB. Hypotensive activity of Lannea coromandelica barks extract. Phytother Res 1996;10:429-30.

14. Jain SK, Tarafder CR. Medicinal plants-lore of the sandals-A revival of PO Bodding's work. Econ Bot 1970;24:241-78.

15. Mhaskar KS, E-Blatter, Caius JF, editors. Kirtikar KR, Basu BD's Indian Medicinal Plants. Vol 3. New Delhi: Sri Satguru Publications; 2000, p.933-6.

16. Shastri K, Chaturvedi G. Charaka Samhita. Varanasi: Chaukhambha Bharti Academy; 2004.

17. Yadava T, Narayana R. Sutra sthana, Sushruta Samhita. 7th edition. Varanasi: Chaukhambha Orientalia; 2002.

18. Sharma S. Chaukhambha Sanskrit Office. Sutra sthana, Ashtanga Sangraha. 2nd edition. Varanasi: Shashilekha Commentary; 2008.

19. Kunte AM, Shastri KR. Chaukhambha Surbharti Prakashan. Uttar sthana Ashtanga Varanasi Hridaya: Sarvanga Sundara and Ayurveda Rasayana Commentary; 2007.

20. Rupinder K, Mohanlal J, Vivek J. Protective effect of Lannea coromandelica Houtt. Merrill. against three common pathogens. J Ayurveda Integr Med 2013;4:224-8.

21. Rahim H, Khan MA, Badshah A, Chishti KA, Khan S, Junaid M. Evaluation of Prunus domestica gum as a novel tablet binder. Braz J Pharm Sci 2014;50:195-202.

22. Lachman L, Lieberman HA, Kanig JL. The theory and practice of industrial pharmacy: evaluation of tablets. 3rd edition. Bombay: Varghese Publishing House; 2003. p. 296-303.

23. Bamiro OA, Sinha VR, Kumar R, Odeku OA. Characterization and evaluation of Terminalia randii gum as a binder in carvedilol tablet formulation. Acta Pharm. Sci 2010;52:254-62.

24. Shivanand P. Instamodel in the development and evaluation of Diclofenac sodium matrix tablet and its effects of release of drug from matrix dosage forms. Int J Pham Life Sci 2010;1:241-5.

25. United States Pharmacopoeia. USP 27. Asian Edition. Washington D.C: United States Pharmacopoeial Convention; 2007, p. 1794-95.

26. Shingala VK, Singh AK, Yadav SK, Sivakumar T. Design and characterization of diclofenac sodium tablets containing Mangifera indica resin as release retardant, Int J Pharm Tech Res 2010;2:2107-11.

27. Satyam G, Shivani S, Garima G, Nitin S, Sharma P.K. Isolation and evaluation of binding property of pappaya starch in diclofenac sodium tablet. Int J Pharm Tech Res 2010;2:1508-12.

28. Silvina $\mathrm{AB}$, Maria CL, Claudio JS. In vitro Studies of diclofenac sodium controlled-release from biopolymeric hydrophilic matrices. J Pharm Pharma Sci 2002;5:213-9. 
29. Nazneen B, Wesely EG, Johnson M. FT-IR studies on the leaves of Albizia lebbeck benth. Int J Pharm Pharm Sci 2012;4:293-6.
Accepted 09 Apr 2016

Revised 29 Feb 2016

Received 01 Sep 2015

Indian J Pharm Sci 2016; 78(2):224-230 